\title{
Variation of carbon storage by different reforestation types in the hilly red soil region of southern China
}

\author{
Hua Zheng ${ }^{\text {a }}$, Zhiyun Ouyang ${ }^{\mathrm{a}, *}$, Weihua $\mathrm{Xu}^{\mathrm{a}}$, Xiaoke Wang ${ }^{\mathrm{a}}$, \\ Hong Miao ${ }^{\mathrm{a}}$, Xiquan $\mathrm{Li}^{\mathrm{b}}$, Yuxin Tian ${ }^{\mathrm{b}}$ \\ ${ }^{a}$ State Key Lab of Urban and Regional Ecology, Research Center for Eco-Environmental Sciences, Chinese Academy of Sciences, Beijing 100085, China \\ ${ }^{\mathrm{b}}$ Hunan Academy of Forestry, Hunan Province, Changsha 410004, China
}

Received 1 July 2007; received in revised form 8 October 2007; accepted 8 October 2007

\begin{abstract}
Reforestation is a mitigation option to reduce increased atmospheric carbon dioxide levels as well as its predicted climate change. As a result, several forestry-based carbon storage projects have been introduced in many countries. To quantify the dynamics of ecosystem carbon allocation as affected by different forest management practices, we measured the above- and belowground biomass accumulation over 14 years, as well as the tissue carbon concentrations of trees in four different types: three monospecific plantations of slash pine (Pinus elliottii) (SPP), Chinese fir (Cunninghamia lanceolata) (CFP), and tea-oil camellia (Camellia oleifera) (TCP) and one natural secondary forest (NSF) (Pinus massoniana and Cyclobalanopsis glauca). A regression equation was constructed using the diameter at breast height/basal diameter (DBH/BD) and elements of total tree biomass. The equation was subsequently utilized to estimate tree carbon storage. The carbon storage of understory, forest floor, and soil components was also estimated. Results indicated that NSF stored significantly more carbon (141.99 t/ha) than SPP (104.07 t/ha), CFP (102.95 t/ ha), and TCP (113.09 t/ha). Most of the carbon was found in the soil pool (60.30\% in SPP, $70.42 \%$ in CFP, $63.87 \%$ in TCP, and 59.36\% in NSF). In addition, more than $60 \%$ of the soil carbon storage at $0-100 \mathrm{~cm}$ depth was stored in the upper $40 \mathrm{~cm}$. With the exception of trees, each component of NSF, including the understudy, forest floor, and soil, possessed significantly higher carbon storage than that of the three plantations ( $p<0.05$ ). Soil surface disturbance during forest management practices was one of the main factors reducing the soil and understory carbon storage of tree plantation stands. These results suggest that natural restoration is a superior approach for increasing the carbon storage potential in the hilly red soil region in reforestation projects compared to plantations. In addition, reducing soil surface disturbance during forest management practices might also play an important factor in improving carbon sequestration potential in above tree plantations.
\end{abstract}

(C) 2007 Published by Elsevier B.V.

Keywords: Biomass; Roots; Soil carbon; Carbon storage; Carbon allocation patterns; Forest restoration

\section{Introduction}

In recent centuries, human activities have fundamentally altered many of the Earth's biogeochemical cycles. The first recognized and most prominent change is the modification of global carbon cycles. Forest ecosystems are a major sink of terrestrial carbon, which is dependent on environmental, biogeochemical, and land-management factors. Changes in land use can have a remarkable effect on the carbon contents in

\footnotetext{
* Corresponding author at: State Key Lab of Urban and Regional Ecology, Research Center for Eco-Environmental Sciences, Chinese Academy of Sciences, Shuangqing Road 18, Haidian District, P.O. Box 2871, Beijing 100085, China. Tel.: +86 10 62849191; fax: +86 1062943822 .

E-mail address: zyouyang@rcees.ac.cn (Z. Ouyang).
}

the ecosystem. Such changes are important from the viewpoint of soil fertility and long-term sustainability, and their influence on atmospheric $\mathrm{CO}_{2}$ and global warming (Bouwman, 1990; Lal, 2007). Reforestation can capture significant amounts of atmospheric carbon, and it is expected to contribute to soil quality and conservation (Schroeder, 1992; Lal, 2004; Nabuurs et al., 2007). However, the effects of tree species composition, developmental stage, soil type, and management practices on forest ecosystem carbon storage should not be neglected (Cannell, 1982; Harmon et al., 1990; Dewar and Cannell, 1992; Grigal and Ohmann, 1992; Lal, 2005; Yang et al., 2005; Nabuurs et al., 2007). To increase the awareness of reforestation as an option for atmospheric $\mathrm{CO}_{2}$ fixation and to understand the effects of different reforestation types as well as management strategies on forest carbon storage, it is necessary to examine 
carbon pools and their changes to determine the most appropriate reforestation species, approaches, and forest management strategies.

In southern China, red soil covers $2.18 \times 10^{6} \mathrm{~km}^{2}$ of 10 provinces (Zhao, 2002). It is also known as the Red Desert due to severe soil erosion and the wide undulating geomorphology of severely eroded land that originated from the destruction of the natural broad-leaf deciduous forests and the attempted replacement of secondary Masson Pine forest in the 1950s. Ecosystem degradation seriously depleted land resources, and the environment was degraded in the hilly red soil region. This instigated the call for soil and water conservation, and restoration of vegetation on the eroded soils (Zhang et al., 2004). Recently, forest restoration in the hilly red soil region has received considerable attention (Peng and Xiao, 1995; Zhao, 2002). This interest is highlighted in the policy of returning farmland to forest in the mid and lower reaches of the Yangtze River which have resulted in extensive re-plantation of farmlands with tea-oil camellia for high economic refund, as well as slash pine and Chinese fir for high-quality timber which cover $1.9 \times 10^{6}$ and $9.1 \times 10^{6}$ ha, respectively $(\mathrm{Ru}, 1995)$. In addition, some fallow farmlands were left for natural regeneration of secondary forest. And now its main species is masson pine, which is used for timber and covers $3.27 \times 10^{7}$ ha in China (Kong and Mo, 2002). Among the studies of the restoration, many investigations have focused on the effects of afforestation or other land uses on soil erosion and surface runoff (Peng and Xiao, 1995; Tian et al., 2002), biodiversity (Peng, 2003), and soil fertility (Zheng et al., 2005). In contrast, few studies examine the change of carbon storage due to different management approaches in the forests of southern China. Quantifying the changes in the size of the carbon pool is fundamental for understanding the effects of different forest management practices on carbon dynamics. Therefore, studies that estimate total carbon fluxes in forest ecosystems under different management practices are urgently needed (Yang et al., 2005).

The main objective of this study is to quantify the dynamics of ecosystem carbon allocation as affected by different forest management practices. For this objective, we assessed the overall impact of four typical reforestation types (i.e., plantations of slash pine, Chinese fir, tea-oil camellia, and natural secondary forest) on ecosystem carbon storage, by means of quantifying above- and belowground carbon pools. This study also provided a management baseline for enhancing the carbon sequestration potential of forest ecosystems.

\section{Methods}

\subsection{Study area}

The study was conducted at the Ecological Benefit Monitoring Station of the Yangtze River Protection Forest, which is located in Hengyang County of Southern Hunan Province $\left(27^{\circ} 05^{\prime} \mathrm{N}, 112^{\circ} 18^{\prime} \mathrm{E}\right)$. Altitude ranges from 86 to $147 \mathrm{~m}$ above sea level. A typical subtropical monsoon climate occurs in this area with an annual mean air temperature of $17.9^{\circ} \mathrm{C}$ and an annual frost-free period of 340 days. Annual rainfall averages $1237 \mathrm{~mm}$, concentrated during the period from May to August. Red soil of the area was formed from arenaceous shale and is approximately $100 \mathrm{~cm}$ thick. According to Soil Taxonomy of China, this soil is classified as a fine loamy, hyperthermic, and acidic Udic Cambisol (Gong, 1999).

In 1989, after all the aboveground vegetation was removed by the local residents for fuel-wood consumption, four forest stands were produced along a slope: three plantations of slash pine (Pinus elliottii) (SPP), Chinese fir (Cunninghamia lanceolata) (CFP), and tea-oil camellia (Camellia oleifera) (TCP), respectively, and a naturally regenerated secondary forest (NSF). Among these species slash pine is exotic species. These forest stands are all located within an area of less than $1 \mathrm{~km}^{2}$, and they are situated on the middle part of the hill with the slope $18-25^{\circ}$. Before re-vegetation, the lands of three plantations were shaped into horizontal belts, and contour planting was employed with a standard of $100 \mathrm{~cm}$ wide and $50 \mathrm{~cm}$ high for the dikes.

After planting, three $20 \mathrm{~m} \times 20 \mathrm{~m}$ plots were established at each forest site. Soils in each plot were sampled by depth $(0$ $20 \mathrm{~cm}$, three replicate cores per plot along a diagonal transect) in April 1989. Soil pH was determined in a 1:2.5 soil-water slurry using a combined glass electrode. Soil organic carbon was also established by the oil-bath $\mathrm{K}_{2} \mathrm{Cr}_{2} \mathrm{O}_{7}$ titration method. Total nitrogen was determined by the semi-micro Kjeldahl method. Available nitrogen was ascertained by a microdiffusion technique after alkaline hydrolysis. Available phosphorus was extracted with a $0.5 \mathrm{~mol} \mathrm{~L}{ }^{-1} \mathrm{NaHCO}_{3}$ solution ( $\mathrm{pH} 8.5$ ). Phosphate-P in solution was analyzed colorimetrically by the formation of a blue phosphomolybdate complex following a reduction with ascorbic acid. Available potassium was measured using the $\mathrm{CH}_{3} \mathrm{COONH}_{4}$ extraction method (Lao, 1988). And edaphic conditions were similar before forest establishment (Table 1).

Until 1998 the tree plantations were managed periodically (every 3-4 years), in order to maintain them as monospecific stands. Management practices included completely loosening the surface soil and clearing grasses and shrubs in surrounding area. No fertilizer was ever applied. Plant residue amassed in the tending process is normally left on the ground. The tea-oil camellia received less management than the other two plantations, resulting in an extensive growth (i.e., 125 individuals $/ \mathrm{m}^{2}$ ) of the herbaceous plant Dicranopteris linearis.

The area where the natural secondary forest regenerated was closed to people in 1989, therefore both disturbances by local residents as well as tree planting were prevented. This area has received no management and is currently dominated by tree species as Pinus massoniana, Cyclobalanopsis glauca, Quercus aliena, Quercus fabri.

\subsection{Biomass estimation}

In July 2003, three $20 \mathrm{~m} \times 20 \mathrm{~m}$ plots were established at each forest site, which were the same ones sampled in 1989. The diameter at breast height (DBH), the basal diameter (BD), and the height of all living trees were measured. A total of forty 
Table 1

Soil properties in the $0-20 \mathrm{~cm}$ depth sampled in 1989 and vegetation properties measured in 2003

\begin{tabular}{|c|c|c|c|c|}
\hline Parameter & SPP & CFP & $\mathrm{TCP}$ & NSF \\
\hline \multicolumn{5}{|l|}{ Soil properties in 1989} \\
\hline Soil bulk density $\left(\mathrm{g} \mathrm{cm}^{-3}\right)$ & $1.38(0.15) \mathrm{a}^{\mathrm{a}}$ & $1.37(0.13) \mathrm{a}$ & $1.36(0.11) \mathrm{a}$ & $1.36(0.04) \mathrm{a}$ \\
\hline $\mathrm{pH}$ & $4.60(0.17) \mathrm{a}$ & $4.60(0.20) \mathrm{a}$ & $4.60(0.30) \mathrm{a}$ & $4.70(0.26) \mathrm{a}$ \\
\hline Soil organic carbon $\left(\mathrm{g} \mathrm{kg}^{-1}\right)$ & $9.71(0.98) \mathrm{a}$ & $10.01(0.93) \mathrm{a}$ & $9.88(0.55) \mathrm{a}$ & $10.70(1.14) \mathrm{a}$ \\
\hline Total nitrogen $\left(\mathrm{g} \mathrm{kg}^{-1}\right)$ & $1.54(0.10) \mathrm{a}$ & $1.61(0.07) \mathrm{a}$ & $1.58(0.07) \mathrm{a}$ & $1.65(0.08) \mathrm{a}$ \\
\hline Available nitrogen $\left(\mathrm{mg} \mathrm{kg}^{-1}\right)$ & $155.65(6.10) \mathrm{a}$ & $159.34(8.45) \mathrm{a}$ & 157.71 (14.99) a & $162.78(16.38) \mathrm{a}$ \\
\hline Available phosphorus $\left(\mathrm{mg} \mathrm{kg}^{-1}\right)$ & $3.25(0.47) \mathrm{a}$ & $3.35(0.38) \mathrm{a}$ & $3.30(0.10) \mathrm{a}$ & $3.40(0.12) \mathrm{a}$ \\
\hline Available potassium $\left(\mathrm{mg} \mathrm{kg}^{-1}\right)$ & $97.40(6.55) \mathrm{a}$ & $98.66(9.04) \mathrm{a}$ & 99.25 (17.7) a & $102.52(21.08) \mathrm{a}$ \\
\hline \multicolumn{5}{|l|}{ Soil and vegetation properties in 2003} \\
\hline Soil organic carbon $\left(\mathrm{g} \mathrm{kg}^{-1}\right)$ & $8.01(0.41) \mathrm{c}$ & $10.67(0.90) b$ & $10.58(0.73) b$ & $14.10(2.22) \mathrm{a}$ \\
\hline Average tree density (per ha) & 2100 & 2967 & 2433 & 1400 \\
\hline Average $\mathrm{DBH} / \mathrm{BD}^{\mathrm{b}}(\mathrm{cm})$ & 10.72 & 7.74 & 2.57 & 10.28 \\
\hline Average tree height $(\mathrm{m})$ & 7.71 & 6.05 & 2.74 & 7.36 \\
\hline
\end{tabular}

${ }^{\text {a }}$ Standard deviations are provided within parentheses. Values in same row followed by the same letter are not significantly different at $p<0.05$ level.

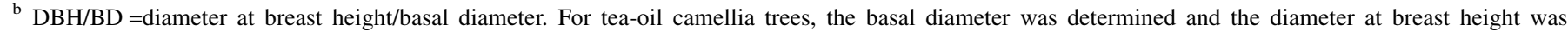
determined for other tree species. SPP =slash pine plantation; CFP =Chinese fir plantation; TCP = tea-oil camellia plantation; NSF = natural secondary forest.

individual trees belonging to five dominant species (i.e., eight individuals of each of the species Pinus elliottii, Cunninghamia lanceolata, Camellia oleifera, Pinus massoniana and Cyclobalanopsis glauca) were harvested for above- and belowground measurements of biomass and tissue carbon concentrations. The selection of the individuals to be harvested was based on the distribution of $\mathrm{DBH} / \mathrm{BD}$ values, in order to have variable stem diameters. And values of DBH/BD of the excavated slash pine (SP), Chinese fir (CF), tea-oil camellia (TC), masson pine (MP), and blue Japanese oak (BJO) trees ranged from 4.25 to16.5, 3.77 to $15.05,0.7$ to $7.1,8.2$ to 23.7 , and 3.2 to $11.1 \mathrm{~cm}$, respectively.

Aboveground biomass was separated into different tissue types (e.g. stem wood, stem bark, coarse branch, fine branch, and foliage). Four to six branches were sampled from each tree at regular intervals over the entire length of the crown. Foliage was collected from each of the sampled branches. The trunk was sectioned into meter-long pieces using a chainsaw. Bark was then collected immediately. All samples were weighed in the field, placed into plastic bags, and kept refrigerated and transported to the lab.

For each tree, all roots with a diameter greater than $2 \mathrm{~mm}$ were collected. Coarse roots $(>2 \mathrm{~mm}$ in diameter) were gathered by starting at the stump and following the roots to their end. Since the tree density was high and much of the root growth was shallow, lateral, it was difficult to distinguish the fine roots of one tree from another. To deal with this problem, large soil blocks $\left(1 \mathrm{~m}^{3}\right.$ each $)$ were excavated around each target tree. The size of these blocks was selected with the assumption that the foreign fine roots collected within the block would be balanced with the intrinsic fine roots left in the soil. No fine roots were collected outside of these blocks. All roots were extracted in the lab from each of these soil blocks by wet sieving and the roots with a diameter smaller than $0.2 \mathrm{~cm}$ were isolated from the roots with $0.2-2 \mathrm{~cm}$ diameter by hand.

Based on foregoing above- and belowground biomass measurement, the allometric biomass functions were derived (log of component, mass $=a \log (\mathrm{DBH})+b$, the coefficients $a$ and $b$ were estimated using a generalized linear model of weight of each biomass component as a function of $\log (\mathrm{DBH})$ ) and subsequent calculation of biomass components (stem, stem bark, branches, foliage, and roots) (Appendix A).

Understory biomass was also determined using destructive sampling techniques (i.e., total harvesting, including roots), within five randomly selected $2 \mathrm{~m} \times 2 \mathrm{~m}$ subplots within each $20 \mathrm{~m} \times 20 \mathrm{~m}$ plot. A total of fifteen $2 \mathrm{~m} \times 2 \mathrm{~m}$ plots were sampled in each forest type.

Forest floor components (i.e., dead plant material on the forest floor) were also sampled within six $1 \mathrm{~m} \times 1 \mathrm{~m}$ subplots randomly chosen in each $20 \mathrm{~m} \times 20 \mathrm{~m}$ plot. A total of eighteen $1 \mathrm{~m} \times 1 \mathrm{~m}$ subplots were sampled in each forest type. All plant materials collected within these $1 \mathrm{~m} \times 1 \mathrm{~m}$ subplots were sorted into three components: coarse wood with a diameter greater than $2 \mathrm{~cm}$ and height at least $40 \mathrm{~cm}$, litter (leaves and twigs), and the fragmentation layer. Forest floor components were bagged separately and transported to the lab.

\subsection{Soil carbon pool}

Volumetric samples of mineral soil were collected at different depths for determining carbon concentrations, as well as bulk density. Three soil samples were taken at two depths (020 and $20-40 \mathrm{~cm}$ ) on five randomly locations along a diagonal transect within each of the $20 \mathrm{~m} \times 20 \mathrm{~m}$ plots. The soil samples were pooled by the sampling location and layer. In addition, samples were taken at 40-60, 60-80, and 80-100 cm depths from six profiles on three plots of each forest type.

\subsection{Sample treatment and chemical analyses}

Sealed tree tissue samples, as well as samples collected from the forest floor and understory were weighed in the field and recorded as wet-weight. They were then oven-dried at $70{ }^{\circ} \mathrm{C}$ and reweighed to calculate tissue-specific wet-to-dry mass conversion factors. 
All plant material samples were ground by means of a mortar and pestle with liquid nitrogen, and the oil-bath $\mathrm{K}_{2} \mathrm{Cr}_{2} \mathrm{O}_{7}$ titration method was used to determine organic carbon (Dong, 1997). Soil samples were air dried and sieved with a $2 \mathrm{~mm}$ mesh to remove any vegetation or gravel. Soils were also analyzed for soil organic carbon by the oil-bath $\mathrm{K}_{2} \mathrm{Cr}_{2} \mathrm{O}_{7}$ titration method (Liu, 1996).

\subsection{Calculation of carbon storage and statistical analyses}

Using the measurements mentioned above, forest carbon storage was calculated as

$$
\begin{aligned}
\mathrm{CT}_{\mathrm{f}}= & \sum_{i=1}^{8}\left(C_{\mathrm{T} i} B_{\mathrm{T} i}\right)+\sum_{j=1}^{2}\left(C_{\mathrm{U} j} B_{\mathrm{U} j}\right)+\sum_{m=1}^{3}\left(C_{\mathrm{F} m} B_{\mathrm{F} m}\right) \\
& +\sum_{n=1}^{5}\left(10^{-6} C_{\mathrm{Sn}} S_{\mathrm{Sn}} \mathrm{BD}_{\mathrm{Sn}} d\right)
\end{aligned}
$$

where $\mathrm{CT}_{\mathrm{f}}$ is the forest carbon storage ( $\left.\mathrm{t} / \mathrm{ha}\right), i$ the tree tissue type (i.e., stem wood, stem bark, coarse branch, fine branch, foliage, $>2 \mathrm{~cm}$ roots, $0.2-2 \mathrm{~cm}$ roots, and $<0.2 \mathrm{~cm}$ roots), $C_{\mathrm{Ti}}$ the carbon concentration of the tree tissue $(\%), B_{\mathrm{T}}$ the biomass of the tree tissue (t/ha), $j$ the understory component (i.e., the above- and belowground), $C_{\mathrm{U}}$ the carbon concentration of the understory component $(\%), B_{\mathrm{U}}$ the understory biomass ( $\left.\mathrm{t} / \mathrm{ha}\right)$, $m$ the forest floor component (i.e., coarse wood, litter, the fragmentation layer), $C_{\mathrm{F}}$ the carbon concentration of the forest floor (\%), $B_{\mathrm{F}}$ the biomass of the forest floor component (t/ha), $n$ the layer of mineral soil $(20 \mathrm{~cm}), C_{\mathrm{S}}$ the carbon concentration of the mineral soil (\%), $S_{\mathrm{s}}$ the area of the calculated soil (ha), $\mathrm{BD}_{\mathrm{s}}$ the bulk density of the measured soil layer $\left(\mathrm{g} \mathrm{cm}^{-3}\right)$, and $d$ is the depth $(20 \mathrm{~cm})$ of the measured soil layer.

We acknowledge that the three $20 \mathrm{~m} \times 20 \mathrm{~m}$ plots established per stand do not constitute true replicates, because they are all within each of the four sites (i.e., SPP, CFP, TCP, and NSF) and no plots were established in other stands with similar forest characteristics. Nevertheless, the fact that these forest stands occur in similar topographic conditions, as well as their similarity in edaphic conditions in 1989 (Table 1), allows us to consider them as different treatments. Therefore, one-way variance analyses were used to test the significant differences in the various soil chemical properties, carbon concentrations, bio- masses, and carbon pools among these treatments. Total forest carbon storage was also compared, including the cumulative carbon storage of trees, understory, forest floor, and soil. When a treatment difference was detected, the Tukey's multiple range test was used to examine the differences of treatment means at the significance level of $p<0.05$. All these statistical analyses were conducted using the SPSS version 11.0.

\section{Results}

\subsection{Changes in tree carbon storage}

With the exception of tea-oil camellia, stem wood constituted approximately $50 \%$ of the entire tree mass (Table 2). For tea-oil camellia, the biomass of coarse branches and foliage accounted for greater than $50 \%$ of the total tree biomass. Although the carbon concentration of all the plant tissues was approximately 50\%, significant differences were observed among specific tissues of the different species (Table 2). Utilizing the weight of the carbon concentration for the different tissue types by the proportion of the total biomass they represented, the average carbon concentration was estimated to be $55.66 \%$ for slash pine, $47.94 \%$ for Chinese fir, $50.34 \%$, for tea-oil camellia, $57.72 \%$ for masson pine, and $48.02 \%$ for blue Japanese oak trees. These data can be used to estimate tree carbon storage using total tree biomass.

The largest tree carbon storage was located in the NSF (35.21 t/ha) and was significantly different from that of CFP and TCP, whereas the smallest storage was located in CFP (19.57 t/ ha) and was significantly different from that of SPP and NSF (Table 3). The carbon storage ranking for above- and belowground was identical to the total tree carbon storage (Table 3).

\subsection{Carbon storage changes of understory and forest floor}

Significant differences in the understory biomass and carbon concentrations were found among the four different forest types (Table 4). Significant differences were also observed among the means of the understory carbon storage (Table 3). Understory carbon storage in the NSF was significantly higher than that of other forest types, but in SPP and CFP it was significantly lower than that of NSF and TCP.

Table 2

\begin{tabular}{|c|c|c|c|c|c|c|c|c|c|c|}
\hline & \multicolumn{5}{|c|}{ Proportion of tissue types (\%) } & \multicolumn{5}{|c|}{ Tissue carbon concentration $(\%)$} \\
\hline & SP & $\mathrm{CF}$ & $\mathrm{TC}$ & MP & BJO & SP & $\mathrm{CF}$ & $\mathrm{TC}$ & MP & $\mathrm{BJO}$ \\
\hline Stem wood & 55.34 & 48.69 & 15.89 & 54.34 & 68.01 & $54.87 \mathrm{~b}(1.49)$ & $47.62 \mathrm{~d}(1.21)$ & $51.21 \mathrm{c}(1.36)$ & 60.68 a (1.72) & $47.68 \mathrm{~d}(1.30)$ \\
\hline Stem bark & 6.02 & 9.91 & 4.29 & 7.82 & 3.88 & 53.31 a (1.43) & $49.03 \mathrm{c}(1.25)$ & $51.33 \mathrm{~b}(1.36)$ & 53.91 a $(1.55)$ & $48.88 \mathrm{c}(1.34)$ \\
\hline Coarse branch & 9.14 & 5.56 & 26.72 & 9.31 & 9.18 & 56.67 a (1.49) & $46.04 \mathrm{e}(1.26)$ & $51.76 \mathrm{c}(1.31)$ & $54.88 \mathrm{~b}(1.60)$ & $48.64 \mathrm{~d}(1.35)$ \\
\hline Fine branch & 2.77 & 8.64 & 8.22 & 7.04 & 3.64 & $55.33 \mathrm{a}(1.43)$ & $45.73 \mathrm{e}(1.25)$ & $50.23 \mathrm{c}(1.26)$ & $53.69 \mathrm{~b}(1.58)$ & $47.85 \mathrm{~d}(1.35)$ \\
\hline Foliage & 12.47 & 12.11 & 28.73 & 7.63 & 6.49 & 58.90 a $(1.50)$ & $50.42 \mathrm{~b}(1.38)$ & $49.37 \mathrm{~b}(1.29)$ & $44.71 \mathrm{c}(1.34)$ & $49.71 \mathrm{~b}(1.42)$ \\
\hline $\operatorname{Root}(>2 \mathrm{~cm})$ & 12.37 & 12.62 & 14.92 & 12.17 & 7.08 & $56.64 \mathrm{~b}(1.46)$ & $48.70 \mathrm{c}(1.34)$ & $48.82 \mathrm{c}(1.36)$ & 59.68 a $(1.82)$ & $48.67 \mathrm{c}(1.41)$ \\
\hline Root $(0.2-2 \mathrm{~cm})$ & 1.33 & 1.05 & 0.74 & 1.13 & 1.38 & $54.85 \mathrm{~b}(1.41)$ & $46.96 \mathrm{c}(1.29)$ & $47.04 \mathrm{c}(1.31)$ & $58.03 \mathrm{a}(1.81)$ & $47.51 \mathrm{c}(1.40)$ \\
\hline Root $(<0.2 \mathrm{~cm})$ & 0.57 & 1.44 & 0.49 & 0.56 & 0.35 & $52.17 \mathrm{~b}(1.33)$ & $45.04 \mathrm{~d}(1.20)$ & $45.51 \mathrm{~d}(1.28)$ & $56.47 \mathrm{a}(1.57)$ & $46.89 \mathrm{c}(1.35)$ \\
\hline
\end{tabular}

Proportion of tissue types in terms of biomass and tissue-specific carbon concentrations ${ }^{\mathrm{a}}$

\footnotetext{
${ }^{\text {a }} \mathrm{SP}=$ slash pine; $\mathrm{CF}=$ Chinese fir; $\mathrm{TC}=$ tea-oil camellia; $\mathrm{MP}=$ masson pine; $\mathrm{BJO}=$ blue Japanese oak. Standard deviations are provided in parenthesis. Values in
} same row followed by the same letter are not significantly different at $p<0.05$ level. 
Table 3

Carbon storage values ( $\mathrm{t} / \mathrm{ha})$ in various components of the four reforestation types ${ }^{\mathrm{a}}$

\begin{tabular}{|c|c|c|c|c|}
\hline Component & SPP & CFP & $\mathrm{TCP}$ & $\mathrm{NSF}$ \\
\hline \multicolumn{5}{|l|}{ Tree } \\
\hline Stem wood & 16.9 (1.9) a & $9.8(0.4) \mathrm{b}$ & $5.7(1.4) \mathrm{c}$ & $19.1(1.7) \mathrm{a}$ \\
\hline Stem bark & $1.7(0.2) \mathrm{a}$ & $1.8(0.1) \mathrm{a}$ & $0.7(0.1) b$ & $2.1(0.4) \mathrm{a}$ \\
\hline Coarse branch & $3.2(0.5) b$ & $1.3(0.1) \mathrm{c}$ & $5.9(1.2) \mathrm{a}$ & $4.0(1.5) b$ \\
\hline Fine branch & $1.1(0.2) \mathrm{c}$ & $1.5(0.03) \mathrm{bc}$ & $2.1(0.5) \mathrm{ab}$ & $2.3(0.5) \mathrm{a}$ \\
\hline Foliage & $4.1(0.5) \mathrm{b}$ & $2.4(0.1) \mathrm{b}$ & $6.7(1.5) \mathrm{a}$ & $3.7(2.2) \mathrm{b}$ \\
\hline Aboveground subtotal & $27.0(3.3) \mathrm{ab}$ & $16.7(0.6) \mathrm{c}$ & $21.1(4.6) \mathrm{bc}$ & $30.6(3.5) \mathrm{a}$ \\
\hline $\operatorname{Root}(>2 \mathrm{~cm})$ & $3.6(0.4) \mathrm{ab}$ & $2.5(0.1) \mathrm{c}$ & $3.0(0.7) \mathrm{bc}$ & $4.1(0.6) \mathrm{a}$ \\
\hline Root $(0.2-2 \mathrm{~cm})$ & $0.4(0.05) \mathrm{a}$ & $0.2(0.01) \mathrm{b}$ & $0.2(0.03) \mathrm{b}$ & $0.4(0.03) \mathrm{a}$ \\
\hline Root $(<0.2 \mathrm{~cm})$ & $0.2(0.02) \mathrm{b}$ & $0.2(0.01) \mathrm{a}$ & $0.03(0.01) \mathrm{c}$ & $0.2(0.03) b$ \\
\hline Belowground subtotal & $4.1(0.5) \mathrm{ab}$ & $2.9(0.1) \mathrm{c}$ & $3.2(0.7) b c$ & $4.6(0.7) \mathrm{a}$ \\
\hline Total & $31.1(3.7) \mathrm{ab}$ & $19.6(0.7) \mathrm{c}$ & $24.3(5.3) \mathrm{bc}$ & $35.2(4.2) \mathrm{a}$ \\
\hline Understory & $8.1(0.1) \mathrm{c}$ & $9.2(1.3) \mathrm{c}$ & $13.8(1.8) \mathrm{b}$ & 19.5 (1.6) a \\
\hline Forest floor & $2.2(0.2) \mathrm{b}$ & $1.7(0.2) b$ & $2.8(0.3) \mathrm{a}$ & $3.0(0.3) \mathrm{a}$ \\
\hline Plant carbon storage & $41.3(4.4) b$ & $30.5(1.1) \mathrm{c}$ & $40.9(3.5) \mathrm{b}$ & $57.7(3.2) \mathrm{a}$ \\
\hline
\end{tabular}

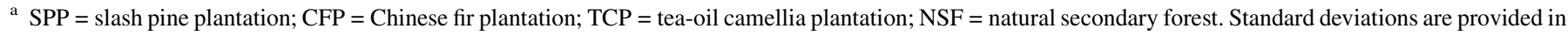
parenthesis. Values in same row followed by the same letter are not significantly different at $p<0.05$ level.

Table 4

Biomass and carbon concentration of understory and forest floor under four reforestation types ${ }^{\mathrm{a}}$

\begin{tabular}{|c|c|c|c|c|c|c|}
\hline \multirow[t]{3}{*}{ Forest } & \multicolumn{3}{|l|}{ Mass (t/ha) } & \multicolumn{3}{|c|}{ Carbon concentration $(\%)$} \\
\hline & \multirow[t]{2}{*}{ Forest floor } & \multicolumn{2}{|l|}{ Understory } & \multirow[t]{2}{*}{ Forest floor } & \multicolumn{2}{|l|}{ Understory } \\
\hline & & Aboveground & Belowground & & Aboveground & Belowground \\
\hline SPP & $3.74(1.00) \mathrm{b}$ & $11.89(2.22) \mathrm{c}$ & $6.90(1.80) \mathrm{c}$ & $57.61(1.52) \mathrm{a}$ & $44.33(1.46) \mathrm{a}$ & $40.82(0.98) \mathrm{b}$ \\
\hline CFP & $3.88(1.07) \mathrm{b}$ & $10.89(3.13) \mathrm{c}$ & $10.34(2.80) b$ & $43.83(1.18) \mathrm{c}$ & $42.55(1.62) b$ & $44.1(1.05) \mathrm{a}$ \\
\hline TCP & $5.75(1.37) \mathrm{a}$ & $19.52(3.82) b$ & $13.78(3.52) \mathrm{a}$ & $49.28(1.35) \mathrm{bc}$ & $42.08(1.53) b$ & $40.26(0.95) \mathrm{b}$ \\
\hline $\mathrm{NSF}$ & $6.03(1.59) \mathrm{a}$ & $31.79(3.93) \mathrm{a}$ & $13.90(3.67) \mathrm{a}$ & $50.11(1.40) \mathrm{b}$ & $43.36(1.56) \mathrm{ab}$ & $40.97(0.98) b$ \\
\hline
\end{tabular}

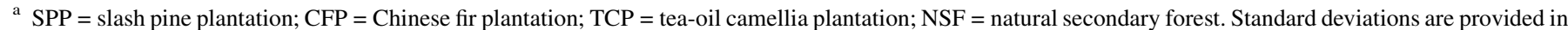
parenthesis. Values in same line followed by the same letter are not significantly different at $p<0.05$ level.

A significant difference was also found among the means of the forest floor components collected in the four different forest types (Table 4). Biomass and carbon storage of the forest floor in the SPP and CFP were significantly lower than those in the TCP and NSF, but no significant difference was observed between TCP and NSF.

\subsection{Soil carbon storage changes}

The combined bulk density and carbon concentration of various soil samples across the forest types provide a general picture of carbon storage at different depths. Significant differences were found when comparing the average surface soil $(0-20 \mathrm{~cm})$ bulk densities and organic carbon concentrations of the four forest types. However, the differences among the forest types decreased with increasing soil depth (Fig. 1).

Adjusted by soil bulk density and organic carbon concentration, the soil organic carbon storage in the 0 $100 \mathrm{~cm}$ range for the four reforestation types was also significantly different, with the highest value $(84.28 \mathrm{t} / \mathrm{ha})$ in the NSF and the lowest value (65.43 t/ha) in the SPP (Fig. 2). Soil organic carbon storage in $0-100 \mathrm{~cm}$ range for the four forest types also decreased with depth. Between 61.97 and
$64.27 \%$ of the total carbon storage was retained in the upper $40 \mathrm{~cm}$ with $32.78-35.91 \%$ stored in the upper $20 \mathrm{~cm}$. In contrast, the percentage of carbon storage in the $80-100 \mathrm{~cm}$ range of soil was only $10.78-11.98 \%$ (Fig. 2).

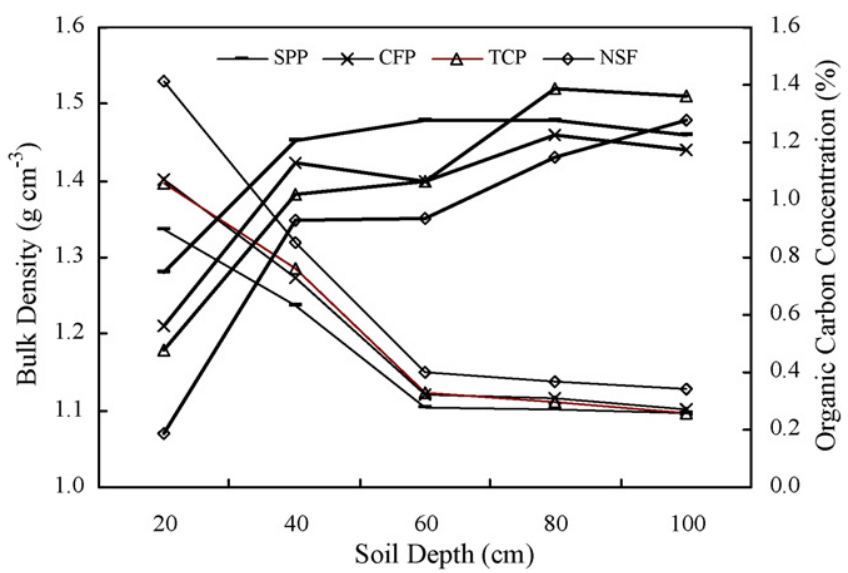

Fig. 1. General pattern of bulk density and organic carbon concentration as affected by depth. Note: SPP = slash pine plantation; $\mathrm{CFP}=$ Chinese fir plantation; TCP = tea-oil camellia plantation; NSF = natural secondary forest. The coarse lines and the thin lines denote bulk density and organic carbon concentration, respectively. 


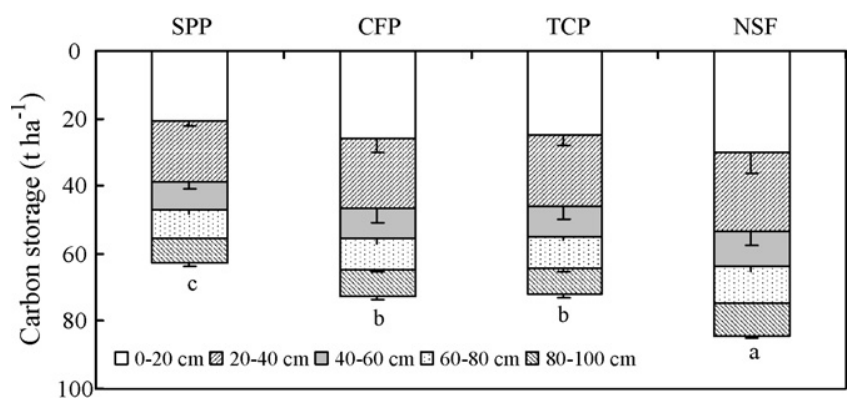

Fig. 2. Soil carbon storage values in the soil $(0-100 \mathrm{~cm})$ in each forest type. Note $: \mathrm{SPP}=$ slash pine plantation; $\mathrm{CFP}=$ Chinese fir plantation; $\mathrm{TCP}=$ tea-oil camellia plantation; NSF = natural secondary forest. Vertical lines denote standard deviations. Values followed by the same letter are not significantly different (0-100 $\mathrm{cm}$ soil carbon storage) at $p<0.05$ level.

\subsection{Changes of ecosystem carbon storage and their allocation patterns}

Fig. 3 summarizes the results obtained for ecosystem carbon storage in each different forest type. Forest carbon storage in NSF was $141.99 \mathrm{t} / \mathrm{ha}$, which was significantly greater than the storage in SPP, CFP, and TCP measured at 104.07, 102.95, and $113.09 \mathrm{t} / \mathrm{ha}$, respectively. The majority of the carbon was located in the soil pool (SPP: $60.30 \%$; CFP: $70.42 \%$; TCP: $63.87 \%$; NSF: $59.36 \%$ ) with only 19.00 $29.86 \%$ in the trees (SPP: 29.86\%; CFP: 19.00\%; TCP: 21.45\%; NSF: $24.80 \%)$. The forest floor and understory contained $7.77-13.72 \%$ and $1.65-2.50 \%$ of ecosystem carbon pools, respectively, which is less than the other components (Fig. 3).

NSF always possessed the highest carbon storage in all components (i.e., trees, understory, forest floor, and upper $100 \mathrm{~cm}$ of soil), with the proportion of carbon storage in the understory and forest floor of the NSF and TCP significantly higher than those of the SPP and CFP (Table 3 and Fig. 3).

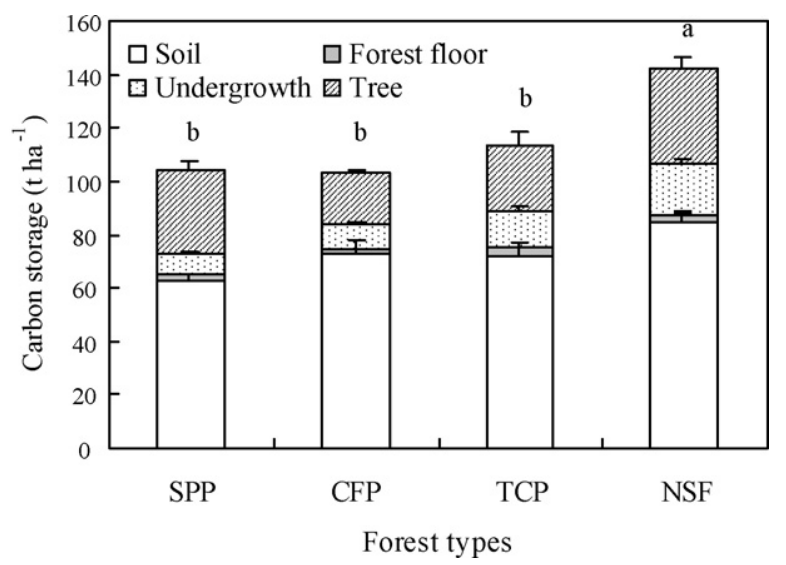

Fig. 3. Carbon storage in various components of each forest type. Note: $\mathrm{SPP}=$ slash pine plantation $; \mathrm{CFP}=$ Chinese fir plantation; $\mathrm{TCP}=$ tea-oil camellia plantation; NSF = natural secondary forest. Vertical lines denote standard deviations. Values followed by the same letter are not significantly different (forest carbon storage) at $p<0.05$ level.

\section{Discussion}

\subsection{Comparison of carbon storage between studied forests and countrywide congeneric forests}

The average carbon storages of litter and forest vegetation of the major Chinese forest types are 8.21 and $57.07 \mathrm{t} / \mathrm{ha}$, respectively (Zhou et al., 2000). As for over-mature masson pine forest ( $>80$ years) and over-mature Chinese fir plantation (>35 years), their average carbon storages are 62.44 and 31.33 t/ha, respectively (Wang and Feng, 2000). But in the study the carbon storages of studied forest are lower than those mentioned above. In addition, the soil carbon storage in studied forest $(65.43-84.28 \mathrm{t} / \mathrm{ha})$ is also lower, compared with the average soil carbon storage in red soil region $(122.8 \mathrm{t} / \mathrm{ha})$ (Wang and Zhou, 1999). Lower carbon accumulation in studied forest and soil might mainly result from younger forest age and shorter restoration time.

Soil carbon storage distributed in the $0-30$ and $0-50 \mathrm{~cm}$ range of soil account for $37-59 \%$ and $62-81 \%$, respectively, of the total carbon storage within the $0-100 \mathrm{~cm}$ of soil range for the global average of forests (Baties, 1996). Detwiler (1986) also reported $35-80 \%$ of carbon storage in the $0-$ $100 \mathrm{~cm}$ soil range was in the $0-40 \mathrm{~cm}$ range in tropical and subtropical soils. The results in this study were consistent with the above results. Approximately $61.97-64.27 \%$ of carbon in the $0-100 \mathrm{~cm}$ range of soil was stored in the $0-$ $40 \mathrm{~cm}$ range, where soils can be disturbed by human disturbances or forest management interventions. Therefore, protection of the topsoil from these disturbances is important for carbon sequestration.

\subsection{Forest management practices and carbon storage allocation patterns}

In this study, forest carbon storage includes the carbon stored in the trees, understory, forest floor, and top soils (i.e., between 0 and $100 \mathrm{~cm}$ ). Because of the different land-management practices, including species selection, land-shaping patterns, and artificial tending patterns, the allocation pattern of forest carbon storage varied significantly.

\subsubsection{Tree level}

Compared with the three plantations, the tree carbon storage in the NSF was significantly higher than that of CFP and TCP, but not significantly different from SPP (Table 3). The difference is believed to result from species selection during reforestation, which was one of the main factors influence ecosystem carbon sequestration (Lal, 2005). After natural restoration for 14 years, NSF developed into a mixed forest dominated by Pinus massoniana and Cyclobalanopsis glauca, an intermediate successional stage before developing into a mature deciduous forest. In addition, the carbon dioxide fixing capacity of a deciduous forest is generally higher than that of a coniferous forest (Zhou et al., 2000). Slash pine is a rapidgrowth exotic species possessing a high carbon fixing potential. In contrast, the tea-oil camellia has a slow growth rate and 
consequently its biomass accumulation was the lowest of the four reforestation types.

\subsubsection{Understory and forest floor}

Carbon storage of understory in the NSF was significantly greater than those of the tree plantations. Soil disturbance and weed control may be the underlying cause of the low understory carbon storage in the tended plantations, particularly in SPP and CFP. Artificial tending during reforestation appears to be an effective approach to accelerate tree growth, which is the initial motive in forest restoration. However, the method of tending used was to loosen the soil and remove the grasses and shrubs. Therefore, the understory trees was directly felled and their growth was seriously disturbed during land-shaping and artificial tending, including vegetation propagules present within the soil. To enhance carbon accumulation in the understory of tree plantations, it would be necessary to loosen the soil only around the base of the trees, rather than completely loosening the soil in the entire plantation. This will also protect vegetation propagules in the soil. With respect to the forest floor, the high biomass of trees and understory present in NSF resulted in higher carbon storages. Similarly, high broad leaf production in the TCP (Zheng et al., 2005), along with high understory biomass, also resulted in high forest floor mass.

\subsubsection{Soil}

Soil was the main carbon pool for all four forest types. The differences in soil carbon storage in the different forest ecosystems are believed to result from the following factors. (1) Soil disturbance decrease soil organic matter. On one hand, artificial tending and land-shaping loosens soil over the entire plantation, break-up macro-aggregates, and exposes previously protected organic matter in soil macro-aggregates (Blair et al., 1995). On the other hand, these management practices accelerated mixing between organic residues and the soil, therefore enhancing microbial activity (Blair et al., 1995). Soil bulk density also increased with the decomposition of the organic matter. (2) Soil and water loss result in a decrease of soil organic carbon. Based on a 5-year observation of the four vegetation types, Tian et al. (2002) reported that the degree of soil and water loss (runoff/ sedimentation) was ranked as $\mathrm{SPP}>\mathrm{CFP}>\mathrm{TCP}>\mathrm{NSF}$, although this pattern was also affected by tree coverage, understory, and soil properties, among others. Lal et al. (2004) also reported that soil carbon loss has come principally from plowing that turns over the soil, making it susceptible to accelerated erosion. Also no-till agriculture reduces the loss of the SOC pool (Lal, 2004). (3) Root biomass and litter production constitute important factors affecting the soil organic carbon. The large root biomass and litter production in NSF and TCP enhanced their surface soil organic carbon contents. The changes in the carbon stocks of the top soils in the different forest types might also reflect the differences in quantity and quality of above- and belowground litter inputs, litter carbon decay (Mo et al., 2002), and root biomass carbon. Yang et al. (2004c) noted that the leaf- litter of Chinese fir possesses higher lignin concentration and lignin/ $\mathrm{N}$ ratio than that of broad leaf tree. In addition, broadleaf trees may allocate more biomass to their roots, especially the fine roots at the shallow soil horizons, which can fix a greater amount of carbon and transfer more root detritus to the top soil (Yang et al., 2004a,b). As for the litter quality of four forest types, Yuan et al. (2003) reported that more than $70 \%$ of the total leaf litter in the TCP and NSF was comprised of easily decomposable broad leaves. In comparison, needle leaf litter, which is more resistant to decomposition, comprised the majority of the total leaf litter in the SPP $(82.90 \%)$ and CFP (69.95\%). Other studies also showed that the loss of SOC stock was attributed to decreased litter input, shifts in abundance of woody and herbaceous vegetation, changes in depth distribution of plant roots, altered soil-water and temperature regimes which accelerate decomposition (Covington, 1981; Johnson et al., 1995; Jackson et al., 2000).

After 14 years of forest growth, the NSF possessed higher carbon pools than those of the three tree plantations evaluated. We believe that these differences could be decreased by reducing the magnitude of human disturbances (e.g. soil disturbance and understory weed control), since these practices affected the carbon allocation patterns.

\subsection{Guidance for forest management approaches to enhance ecosystem carbon sequestration potential}

In this study, natural restoration plays an important role in enhancing ecosystem carbon sequestration potential. In afforestation, improper land-shaping and artificial tending not only decreased soil carbon accumulation during plantation growth, but also reduced the carbon storage in the understory and forest floor. Loosening the soil only around the base of trees, instead of loosening the soil over the entire plantation may aid in greatly improving soil and vegetation carbon storage, as well as land productivity. And doing this would be less costly and labor intensive than the current methods.

As previously discussed, more than $60 \%$ of the carbon storage for the $0-100 \mathrm{~cm}$ range of the soil was sequestered in the top $0-40 \mathrm{~cm}$. As the majority of management activities occur on these top soils, these activities have a significant effect on the carbon storage capacity of these plantation ecosystems. Therefore, protecting the organic carbon of surface soils during forest management activities plays a crucial role in improving the carbon storage and land productivity of tree plantations.

\section{Acknowledgements}

The authors gratefully acknowledge the support of the National Natural Science Foundation of China (30600474) and the Innovation Group Project of National Natural Science Foundation of China (40621061). The authors thank Jiang Dali for collecting, processing, and analyzing samples. Our thanks also go to Andrés Viña for his valuable comments. 


\section{Appendix A}

DBH-based equations for the biomass of stem, stem bark, coarse branches, fine braches, foliage, root $(>2 \mathrm{~cm})$, root $(0.2-2 \mathrm{~cm})$, and root $(<0.2 \mathrm{~cm})$ (M.S.E. $=$ mean square error)

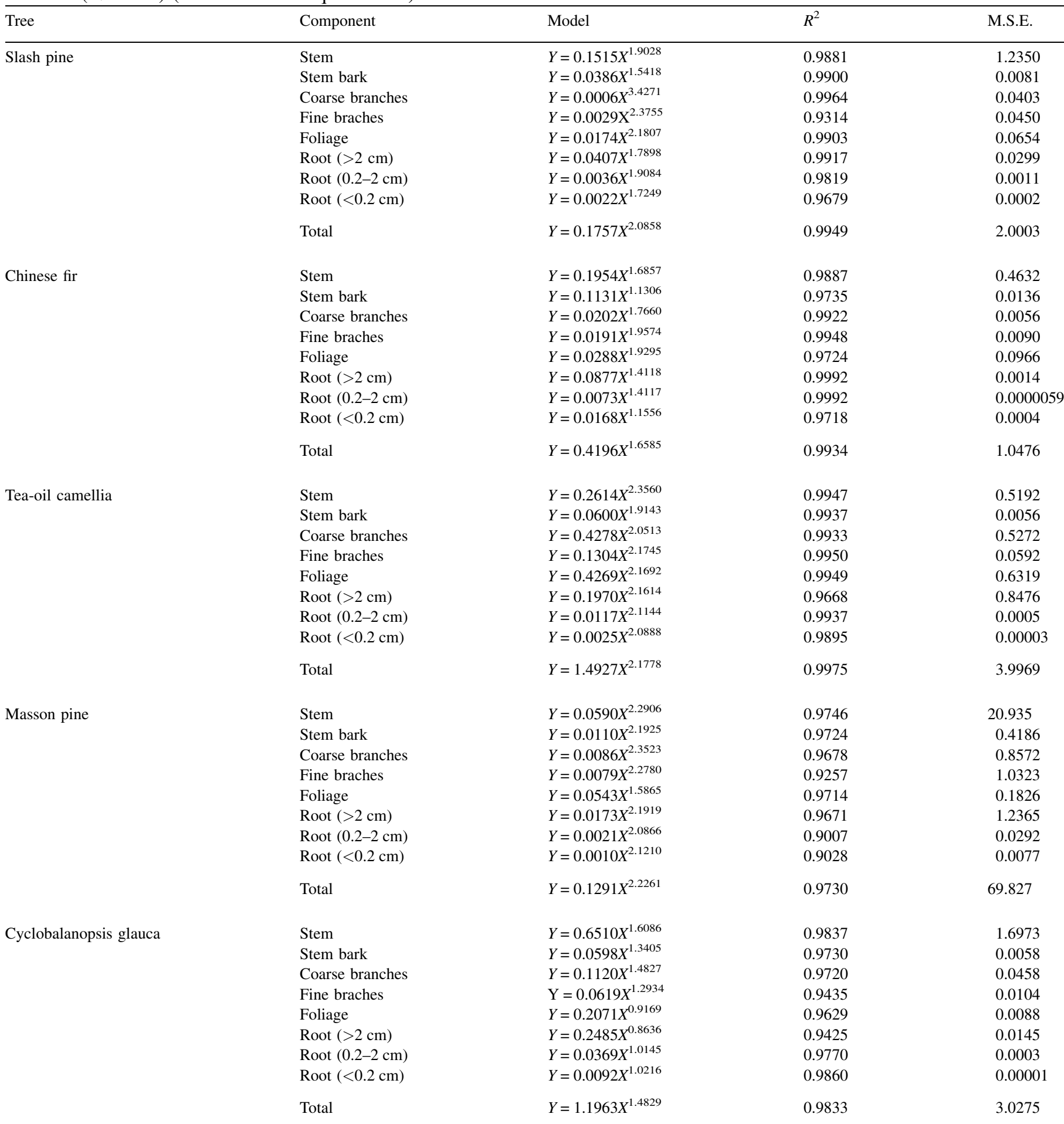

\section{References}

Baties, N.H., 1996. Total carbon and nitrogen in the soils of the world. Eur. J. Soil Sci. 47, 151-163.

Blair, G.J., Lefroy, R.D.B., Lise, L., 1995. Soil carbon fractions baed on their degree of oxidation, and the development of a carbon management index for agricultural systems. Aus. J. Agric. Res. 46, 1459-1466.
Bouwman, A.F., 1990. Exchange of greenhouse gases between terrestrial systems and the atmosphere. In: Bouwman, A.F. (Ed.), Soils and the Greenhouse Effect. Wiley, Chichester.

Cannell, M.G.R., 1982. World Forest Biomass and Primary Production Data. Academic Press, London.

Covington, W.W., 1981. Changes in forest floor organic matter and nutrient content following clear cutting in northern hardwoods. Ecology 62, 41-48. 
Detwiler, R.P., 1986. Land use change and the global carbon cycle: the role of tropical soil. Biogeochemistry 2, 67-93.

Dewar, R.C., Cannell, M.G.R., 1992. Carbon sequestration in the trees, products and soils of forest plantations: an analysis using UK examples. Tree Physiol. $11,49-71$.

Dong, M., 1997. Survey. In: Observation and Analysis of Terrestrial Biocommunities, Standards Press of China, Beijing (in Chinese).

Gong, Z.T., 1999. Chinese Soil Taxonomy. Science Press, Beijing (in Chinese).

Grigal, D.F., Ohmann, L.F., 1992. Carbon storage in upland forests of the Lake States. Soil Sci. Soc. Am. J. 56, 935-943.

Harmon, M.E., Ferrell, W.K., Franklin, J.F., 1990. Effects on carbon storage of conversion of old-growth forests to young forests. Science 247, 699-702.

Jackson, R.B., Schenk, H.J., Jobbagy, E.G., Canadell, J., Colello, G.D., Dickinson, R.E., Field, C.B., Friedlingstein, P., Heimann, M., Hibbard, K., Kicklighter, D.W., Kleidon, A., Neilson, R.P., Parton, W.J., Sala, O.E., Sykes, M.T., 2000. Belowground consequences of vegetation change and their treatment in models. Ecol. Appl. 10 (2), 470-483.

Johnson, C.E., Driscoll, C.T., Fahey, T.J., Siccama, T.G., Hughes, J.W., 1995. Carbon dynamics following clear cutting of a northern hardwood forest. In: McFee, W., Kelly, J.M. (Eds.), Carbon Forms and Functions in Forest Soils. Soil Sci. Soc. Am., Madison, WI, pp. 463-487.

Kong, G.H., Mo, J.M., 2002. Population dynamics of a human-impacted mason pine plantation in Dinghushan. J. Trop. Subtrop. Bot. 10 (3), 193-200. (in Chinese).

Lal, R., 2004. Soil carbon sequestration impacts on global climate change and food security. Science 304, 1623-1627.

Lal, R., 2005. Forest soils and carbon sequestration. Forest Ecol. Manage. 220, 242-258.

Lal, R., 2007. Carbon sequestration. Phil. Trans. R. Soc. B 1-16 doi:10.1098/ rstb.2007.2185.

Lal, R., Griffin, M., Apt, J., Lave, L., Morgan, M.G., 2004. Managing soil carbon. Science 304, 393.

Lao, J.C., 1988. Handbook for Soil and Agro-chemical Analysis. Chinese Agriculutural Press, Beijing (in Chinese).

Liu, G.S., 1996. Soil Physical and Chemical Analysis and Description of Soil Profiles. Standards Press of China, Beijing (in Chinese).

Mo, J.M., Sandra, B., Peng, S.L., Kong, G.H., Zhang, D.Q., Zhang, Y.C., 2002. Role of understory plants on nutrient cycling of a restoring degraded pine forests in a MAB reserve of subtropical China. Acta Ecol. Sinica 22 (9), 1407-1413 (in Chinese).

Nabuurs, G.J., Masera, O., Andrasko, K., Benitez-Ponce, P., Boer, R., Dutschke, M., Elsiddig, E., Ford-Robertson, J., Frumhoff, P., Karjalainen, T., Krankina, O., Kurz, W.A., Matsumoto, M., Oyhantcabal, W., Ravindranath, N.H., Sanz Sanchez, M.J., Zhang, X., 2007. In: Metz, B., Davidson, O.R., Bosch, P.R., Dave, R., Meyer, L.A. (Eds.), Forestry In Climate Change 2007: Mitigation. Contribution of Working Group III to the Fourth Assessment Report of the Intergovernmental Panel on Climate
Change, vol. 555. Cambridge University Press, Cambridge, United Kingdom, New York, NY, USA, pp. 576.

Peng, S.L., 2003. Study and Application of Restoration Ecology in Tropical and Subtropical China. Science Press, Beijing (in Chinese).

Peng, T.B., Xiao, Q.Y., 1995. Study on Sustainable Development of Agriculture in Hilly Red Soil Region. Northern Hunan Province Science Press, Beijing (in Chinese).

Ru, Z.Z., 1995. Monograph of optimal cultivation technology for Pinus elliottii. Guangdong Forest. Sci. Technol 11 (4), 2 (in Chinese).

Schroeder, P., 1992. Carbon storage potential of short rotation tropical tree plantations. Forest Eco. Manage. 50, 31-41.

Tian, Y.X., Li, X.Q., Yuan, Z.K., He, Y.J., Chen, X.P., Ni, A.P., 2002. Studies on benefit of soil and water conservation of different forest types in red soil regions of South Hunan. Res. Soil Water Conserv. 9 (4), 80-82. (in Chinese).

Wang, S.Q., Zhou, C.H., 1999. Estimating soil carbon reservoir of terrestrial ecosystem in China. Geog. Res. 18 (4), 349-356 (in Chinese).

Wang, X.K., Feng, Z.W., 2000. The potential to sequestrate atmospheric carbon through forest ecosystems in China. Chin. J. Ecol. 19 (4), 72-74 (in Chinese).

Yang, Y.S., Chen, G.S., Guo, J.F., Lin, P., 2004a. Decomposition dynamic of fine roots in a mixed forest of Cunninghamia lanceolata and Tsoongiodendron odorum in mid-subtropicals. Ann. Forest Sci. 61, 65-72.

Yang, Y.S., Chen, G.S., Lin, P., Xie, J.S., Guo, J.F., 2004b. Fine root distribution, seasonal pattern and production in four plantations compared with a natural forest in subtropical China. Ann. Forest Sci. 61, 617-627.

Yang, Y.S., Guo, J.F., Chen, G.S., Lin, R.Y., Cai, L.P., Lin, P., 2004c. Litterfall, nutrient return, and leaf-litter decomposition in four plantations compared with a natural forest in subtropical China. Ann. Forest Sci. 61, 465-476.

Yang, Y.S., Guo, J.F., Chen, G.S., Xie, J.S., Zhen, L., Zhao, J., 2005. Carbon and nitrogen pools in Chinese fir and evergreen broadleaved forests and changes associated with felling and burning in mid-subtropical China. Forest Ecol. Manage. 216 (1-3), 216-226.

Yuan, Z.K., Lang, N.J., Wu, Q.X., 2003. Configured Techniques of Protection Forests System Construction in Altiplano and Hilly Region of Yangze River Mid-low Reaches-Study and Demonstration. Hunan Science and Technology Press, Changsha (in Chinese).

Zhang, B., Yang, Y.S., Zepp, H., 2004. Effect of vegetation restoration on soil and water erosion and nutrient losses of a severely eroded clayey Plinthudult in southeastern China. Catena 57, 77-90.

Zhao, Q. G., 2002. The Red Soil Material Cycling and its Regulation, Beijing, Science Press (in Chinese with English summary).

Zheng, H., Ouyang, Z.Y., Wang, X.K., Miao, H., Zhao, T.Q., Peng, T.B., 2005. How different reforestation approaches affect red soil properties in southern China. Land Degrad. Dev. 16, 387-396.

Zhou, Y.R., Yu, Z.L., Zhao, S.D., 2000. Carbon storage and budget of major Chinese forest types. Acta Phytoecol. Sinica 24 (5), 518-522 (in Chinese). 